\title{
Xanthohumol, a prenylated chalcone derived from hops, inhibits proliferation, migration and interleukin-8 expression of hepatocellular carcinoma cells
}

\author{
CHRISTOPH DORN $^{1}$, THOMAS S. WEISS ${ }^{2}$, JÖRG HEILMANN ${ }^{3}$ and CLAUS HELLERBRAND ${ }^{1}$ \\ ${ }^{1}$ Department of Internal Medicine I, ${ }^{2}$ Center for Liver Cell Research, Department of Surgery, and \\ ${ }^{3}$ Institute of Pharmacy, University of Regensburg, D-93042 Regensburg, Germany
}

Received July 27, 2009; Accepted September 10, 2009

DOI: 10.3892/ijo_00000517

\begin{abstract}
Xanthohumol, the major prenylated chalcone found in hops, is well known to exert anti-cancer effects, but information regarding the impact on hepatocellular carcinoma (HCC) cells and potential adverse effects on non-tumorous hepatocytes is limited. Here, we show that xanthohumol at a concentration of $25 \mu \mathrm{M}$ induced apoptosis in two HCC cell lines (HepG2 and Huh7). Furthermore, xanthohumol repressed proliferation and migration, as well as TNF induced NF- $\mathrm{BB}$ activity and interleukin- 8 expression in both cell lines at even lower concentrations. In contrast, xanthohumol concentrations up to $100 \mu \mathrm{M}$ did not affect viability of primary human hepatocytes in vitro. In summary, our data showed that xanthohumol can ameliorate different pro-tumorigenic mechanisms known to promote HCC progression, indicating its potential as promising therapeutic agent that selectively affects cancer cells.
\end{abstract}

\section{Introduction}

Xanthohumol (XN) is the principal prenylated chalcone of the female inflorescences (hop cones, hops) of the hop plant Humulus lupulus L. XN has been shown to have several biological activities, and its anti-tumorigenic effect on different types of cancer cells including colon, ovarian, breast and prostate cancer or fibrosarcoma is most extensively investigated (1-6). These studies revealed that XN inhibits tumor growth and angiogenesis and induces apoptosis of tumor cells. However, so far only limited information is available regarding the effects of $\mathrm{XN}$ on hepatocellular carcinoma (HCC) or HCC cells, respectively.

$\mathrm{HCC}$ is one of the most frequent malignant tumors worldwide with an incidence still rising (7-9). Morbidity and

Correspondence to: Dr Claus Hellerbrand, Department of Internal Medicine I, University Hospital Regensburg, D-93042 Regensburg, Germany

E-mail: claus.hellerbrand@klinik.uni-regensburg.de

Key words: xanthohumol, chalcone, hepatocellular carcinoma, apoptosis, proliferation, migration mortality correlate directly with surgical resectability of the primary tumor. However, outcome is mostly poor, since most patients are diagnosed at an advanced stage, and only 10-20\% of HCCs can be resected completely $(10,11)$. Hence, limited treatment options and the poor prognosis of HCC emphasize the importance of developing novel therapeutics for this highly aggressive tumor.

Hops are used to add bitterness and flavor to beer, and therefore, beer is the major dietary source of $\mathrm{XN}$. Due to the poor solubility in aqueous solutions the average content of $\mathrm{XN}$ in beer is most likely not sufficient to produce a protective effect in humans. However, $\mathrm{XN}$ is present in hops in concentrations around $1 \%$ of the dry weight. In light of the known biological effects of XN on tumors of different entities it appears worthwhile to further study the potential of $\mathrm{XN}$ to ameliorate HCC development and progression. In addition to its anti-tumorigenic efficacy every potential therapeutic compound has to be tested regarding potential adverse effects on the liver, as the main metabolizing organ. This is even more important in case of HCC since this tumor develops in the majority of cases in a cirrhotic liver where the metabolic capacity is restricted and hepatocytes are fragile (7-9). Therefore, the aim of the present study was to analyze the effects of XN on HCC cells as well as on primary human hepatocytes.

\section{Materials and methods}

Cell isolation and culture. HepG2 (ATCC HB-8065) and Huh7 (JCR B0403) cells were cultured as described $(12,13)$. Isolation and culture of primary human hepatocytes $(\mathrm{PHH})$ were performed as described previously (12-14). Human liver tissue for cell isolation was obtained from the charitable state controlled foundation HTCR, with informed patient consent and approved by the local Ethics Committee.

Chemicals. Xanthohumol was obtained from Alexis Biochemicals (Lausen, Switzerland) with a purity $\geq 98 \%$ determined by HPLC. For in vitro experiments XN was dissolved in DMSO and added to cell culture at the indicated concentrations. Samples indicated as controls contained vehicle (DMSO) only. TNF was obtained from R\&D Systems (Wiesbaden-Nordenstadt, Germany), all other chemicals from Sigma Pharmaceuticals (Hamburg, Germany). 
A
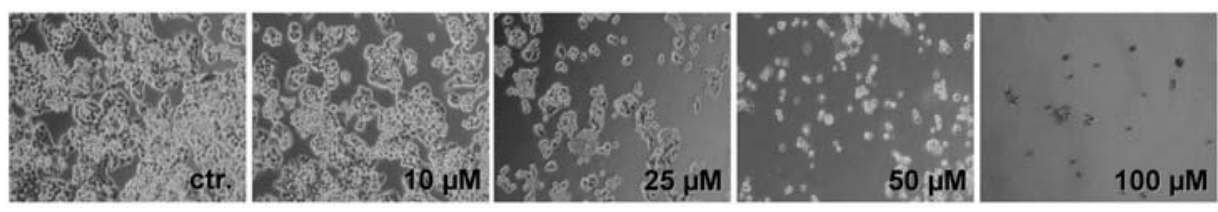

B
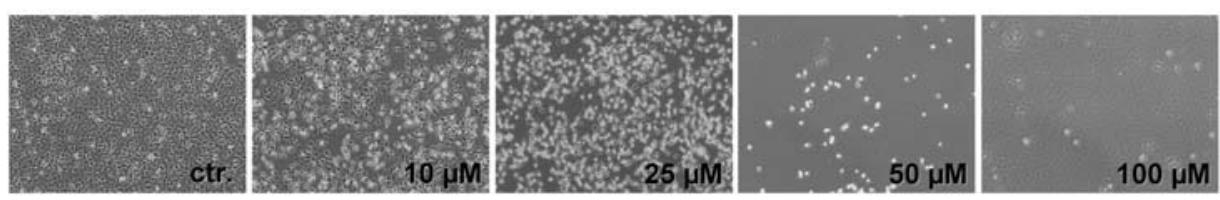

C
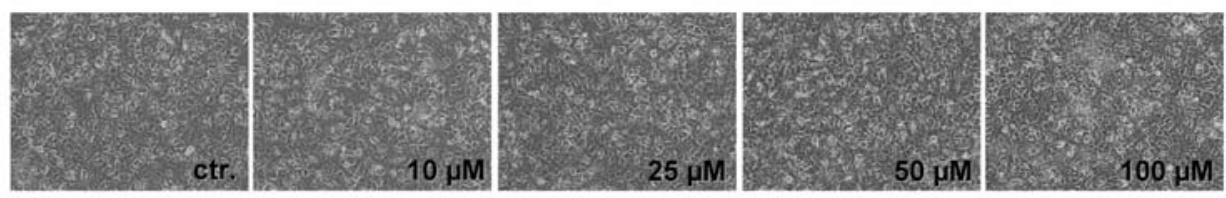

D
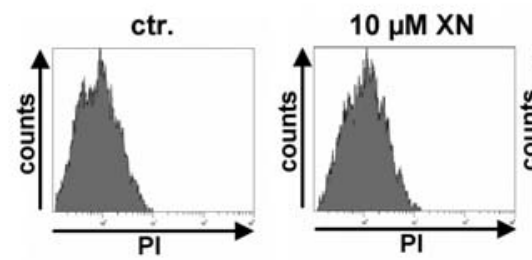

$25 \mu \mathrm{M} \times \mathrm{N}$

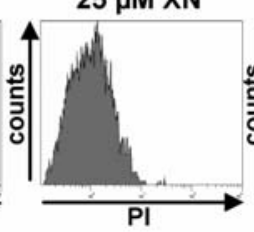

$50 \mu \mathrm{M} X \mathrm{~N}$

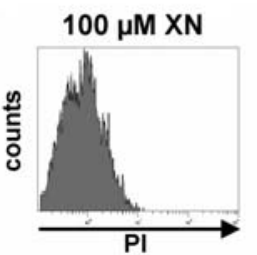

Figure 1. Effect of Xanthohumol on viability of HCC cells and primary hepatocytes. Representative phase-contrast images of (A) HepG2 and (B) Huh7 hepatocellular carcinoma cell line cultures and (C) cultures of primary human hepatocytes ( $\mathrm{PHH}$ ) after $24 \mathrm{~h}$ incubation with the indicated concentrations of xanthohumol (XN). (D) Flow cytometry analysis of propidium iodide (PI) stained PHH incubated with different XN concentrations for $24 \mathrm{~h}$. Experiments were performed in triplicate and were repeated at least twice.

Analysis of caspase-3 activity. The Apo-one Homogeneous Caspase-3/7 Assay (Promega, Madison, WI, USA) was used to analyze caspase-3 activity in HCC cells according to the manufacturer's instructions. Further, active caspase-3 was quantified by flow cytometry using the CaspGLOW Fluorescein Active Caspase-3 Staining kit (BioCat, Heidelberg, Germany) according to manufacturer's instructions. Briefly, HCC cells were seeded in 6-well plates $\left(20,000\right.$ cells $\left./ \mathrm{cm}^{2}\right)$ and incubated with specific concentrations of XN in DMEM containing $10 \% \mathrm{FCS}$ at $37^{\circ} \mathrm{C}$ for $24 \mathrm{~h}$. Subsequently, cells were washed two times with PBS, detached by trypsination, resuspended in DMEM supplemented with $10 \%$ FCS and incubated with the FITC-conjugated caspase-3 inhibitor (FITC-DEVD-FMK) for $30 \mathrm{~min}$. Thereafter, cells were washed with the provided washing buffer and analyzed by flow cytometry using a Coulter EPICS XL flow cytometer (Beckman Coulter, Krefeld). Percentages of FITC positive (active caspase-3) cells of 10,000 analyzed cells were evaluated with the Expo32 ADC Software version 1.1C (Beckman).

Analysis of propidium iodide incorporation by flow cytometry. For determination of viability, cells were incubated with propidium iodide (PI) (Pharmingen, Heidelberg, Germany) and PI incorporation was quantified by flow cytometry as described (15).

Proliferation assay. Cell proliferation was measured using the XTT assay (Roche Diagnostic, Mannheim, Germany) according to the manufacturer's instructions as described (16).
Migration assay. Migration potential of HCC cells was quantified using the Cultrex 96 Well Cell Migration Assay (Trevigen, Gaithersburg, USA) according to the manufacturer's instructions. Briefly, HCC cells were seeded into the upper compartment of the provided 96 -well plate $(40,000$ cells/well) in DMEM supplemented with $\mathrm{XN}$ in specific concentrations as indicated. The lower compartment was filled with DMEM supplemented with conditioned medium from fibroblasts and $10 \%$ FCS as chemoattractants. After incubation at $37^{\circ} \mathrm{C}$ for $5 \mathrm{~h}$ cell migration was quantified by fluorimetry with an EMax Microplate Reader (MWG Biotech, Ebersberg, Germany). Further, migration was assessed by Boyden chamber assays as described (17).

Quantification of activated nuclear $N F-\kappa B$ concentration. $\mathrm{NF}-\kappa \mathrm{B}$ was quantified in nuclear extracts with the ELISAbased kit TransAm NF-кB p65 from Active Motif (Rixensart, Belgium) as described (18).

Expression analysis. Isolation of total cellular RNA from cultured cells and reverse transcription were performed as described (19). IL-8 mRNA expression was quantified using LightCycler real-time PCR technology (Roche) as described (12) applying the following pair of primers: IL-8 forward: 5'-TCTGCAGCTCTGTGTGAAGGTGCAGTT-3' and IL-8 reverse: 5'-AACCCTCTGCACCCAGTTTTCCT-3'.

Statistical analysis. Values are presented as mean \pm SEM. Comparison between groups was made using the Student's unpaired t-test. Welch's correction was performed when 
A

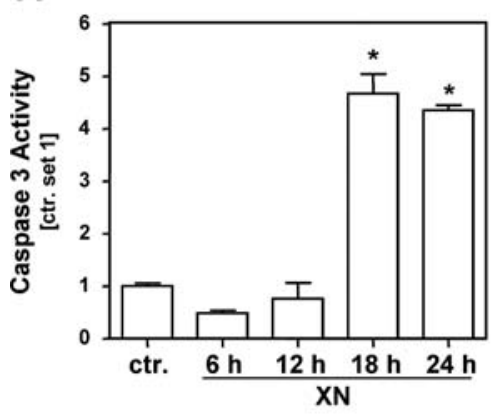

B

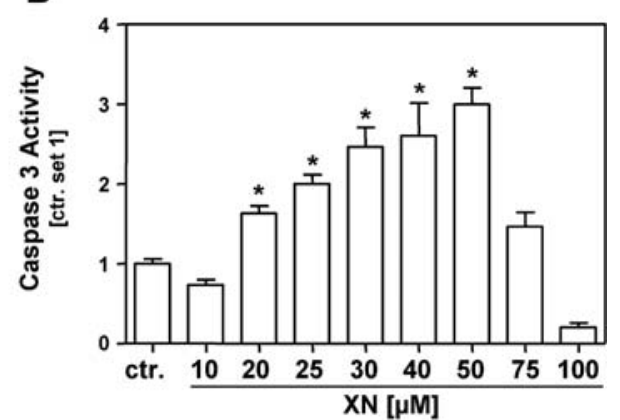

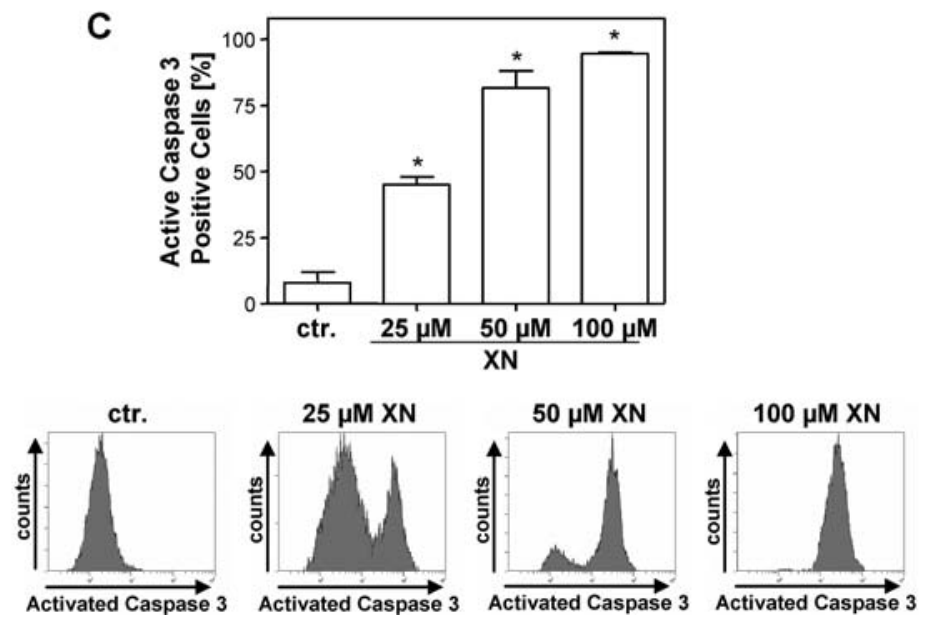

Figure 2. Xanthohumol induced apoptosis in HCC cells. (A) Caspase-3 activity in HepG2 cells stimulated with xanthohumol (XN) at a concentration of $25 \mu \mathrm{M}$ for the time intervals indicated. (B) Caspase-3 activity in Huh7 cells stimulated for $24 \mathrm{~h}$ with different XN concentrations as indicated. (C) Percentage of Huh7 cells with active caspase- 3 after treatment with $\mathrm{XN}$ at indicated concentrations for $24 \mathrm{~h}$ determined by flow cytometry. ${ }^{*} \mathrm{p}<0.05$, experiments were performed in triplicate and were repeated at least twice.

required. A p $<0.05$ was considered statistically significant. All calculations were performed using the statistical computer package GraphPad Prism version 4.00 for Windows (GraphPad Software, San Diego, CA, USA).

\section{Results}

Xanthohumol induces cell death in HCC cells, but not in primary hepatocytes. First, we analyzed the effects of xanthohumol (XN) on the viability of the two human HCC cell lines HepG2 and Huh7. Microscopic observation revealed a marked decrease of the cell number after incubation with $\mathrm{XN}$ at a concentration of $25 \mu \mathrm{M}$ for $24 \mathrm{~h}$. Stimulation with higher XN concentrations led to an almost complete cell detachment (Fig. 1A and B). Consistently, a significant increase of LDH levels was detected in the supernatants of HCC cells after incubation with 25 and $50 \mu \mathrm{M} \mathrm{XN}$ (data not shown). In contrast, primary human hepatocytes (PHH) appeared completely unaffected after $24 \mathrm{~h}$ incubation with XN concentrations as high as $100 \mu \mathrm{M}$ (Fig. 1C). To confirm this finding, $\mathrm{PHH}$ were detached by trypsination and stained with propidium iodide (PI), revealing no significant PI incorporation at any $\mathrm{XN}$ concentration up to $100 \mu \mathrm{M}$ (Fig. 1D).

Xanthohumol induces apoptosis in HCC cells. To further study the underlying mechanisms leading to HCC cell death upon stimulation with $\mathrm{XN}$ we measured the time-dependent activation of caspase-3 in HepG2 cells incubated with $25 \mu \mathrm{M}$ $\mathrm{XN}$ within $24 \mathrm{~h}$. After $12 \mathrm{~h}$ incubation caspase- 3 activity was unaltered, but $6 \mathrm{~h}$ later a significant increase was observed remaining on this elevated level (Fig. 2A). A similar time course of caspase- 3 activation induction was observed in Huh7 cells (data not shown).

Next, the effect of different XN concentrations on caspase-3 activity in Huh7 and HepG2 cells were analyzed revealing a concentration dependent increase of caspase-3 activity in both cell lines, reaching a maximum at $50 \mu \mathrm{M} \mathrm{XN}$ (Fig. 2B, data for HepG2 not shown). At higher XN concentrations HCC cells detached, and accurate analysis of the caspase- 3 was not possible with an ELISA based assay. To bypass this pitfall we additionally performed flow cytometry analysis, applying a FITC-labeled antibody against active caspase-3. Here, basically all Huh7 (Fig. 2C) and HepG2 (data not shown) cells revealed a positive signal for active caspase-3 $24 \mathrm{~h}$ after stimulation with $100 \mu \mathrm{M}$ XN.

Xanthohumol inhibits proliferation and migration of HCC cells. To further characterize the effect of $\mathrm{XN}$ on HCC cells, we performed the XTT assay (see Materials and methods) with both cell lines using different XN concentrations. Proliferation was significantly inhibited after incubation with $15 \mu \mathrm{M}$ $\mathrm{XN}$, whereas concentrations higher than $30 \mu \mathrm{M}$ completely abrogated cell proliferation in HepG2 (Fig. 3A) and Huh7 (Fig. 3B) cells. 
A

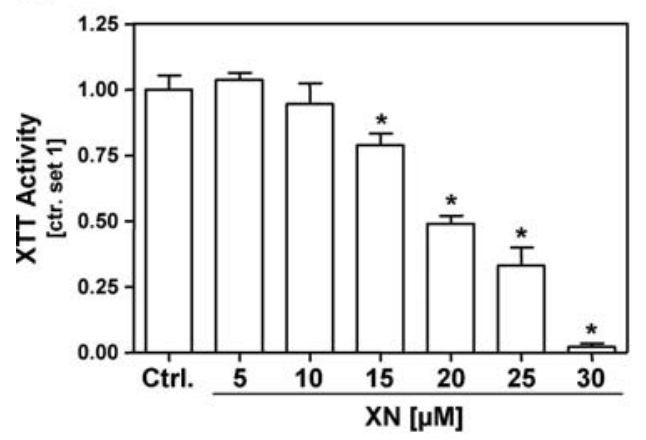

B

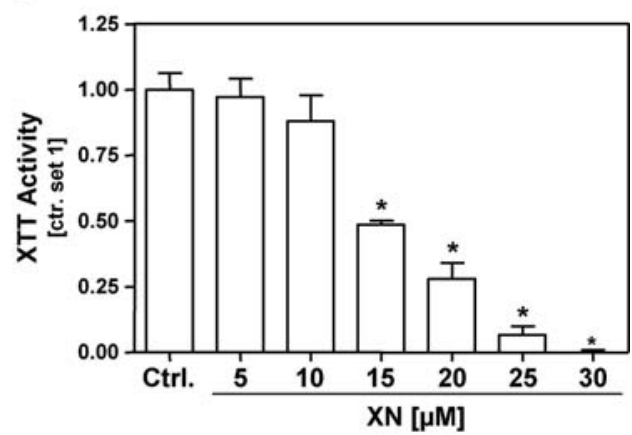

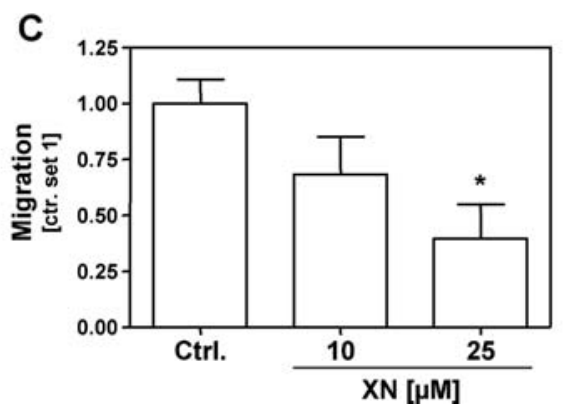

Figure 3. Effect of Xanthohumol on proliferation and migration of HCC cells. Proliferation of (A) HepG2 and (B) Huh7 cells 72 h after stimulation with different concentrations of xanthohumol (XN) relative to control cells (set to 1). (C) Quantification of migration of Huh7 cells incubated with $\mathrm{XN}$ (10 or $25 \mu \mathrm{M}$ ) in comparison to untreated control cells (set to 1 ). ${ }^{*} \mathrm{p}<0.05$, experiments were performed in triplicate and were repeated at least twice.

Next, we analyzed whether $\mathrm{XN}$ affects the migration potential of HCC cells in vitro. For these experiments the Cultrex cell migration assay (see Materials and methods) was used and a short time span of $5 \mathrm{~h}$ was chosen to exclude proapoptotic or anti-proliferative effects of $\mathrm{XN}$ in the applied concentrations $(10$ or $25 \mu \mathrm{M})$. Noteworthy, we observed a significant inhibition of cell migration of Huh7 cells treated with $25 \mu \mathrm{M} \mathrm{XN}$ as compared to untreated control cells (Fig. 3C; similar data of HepG2 cells not shown).

Xanthohumol inhibits $N F-\kappa B$ activation and $I L-8$ expression

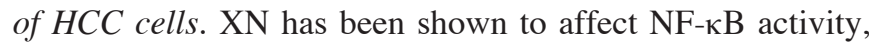
and we and others have shown that NF- $\mathrm{BB}$ plays an important role in hepatocarcinogenesis $(17,20,21)$. Thus, we further

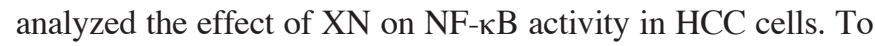
avoid potential paracrine side effects of dead HCC cells on $\mathrm{NF}-\kappa \mathrm{B}$ activity we chose a non-toxic $\mathrm{XN}$ concentration of $2.5 \mu \mathrm{M}$ and stimulated the cells for only $3 \mathrm{~h}$. In this case, $\mathrm{XN}$ exhibited no effects on basal NF- $\mathrm{KB}$ activity in either cell line. However, TNF (10 ng/ml)-induced NF- $\mathrm{KB}$ activity was significantly blunted in $\mathrm{XN}$ treated Huh7 cells even at this low concentration (Fig. 4A).

Next, we analyzed the effect of XN on IL- 8 expression in HCC cells, since IL-8 expression is known to be regulated by NF- $\mathrm{KB}$ in HCC cells (22-24), and previous studies indicated that IL-8 is directly or indirectly involved in the progression of HCC $(24,25)$. In accordance with the effects on NF-кB activity, basal IL-8 expression was not affected by stimulation with XN for $24 \mathrm{~h}$, however, TNF induced IL-8 expression was significantly lower in Huh7 cells preincubated with $\mathrm{XN}$ as compared to controls (Fig. 4B).
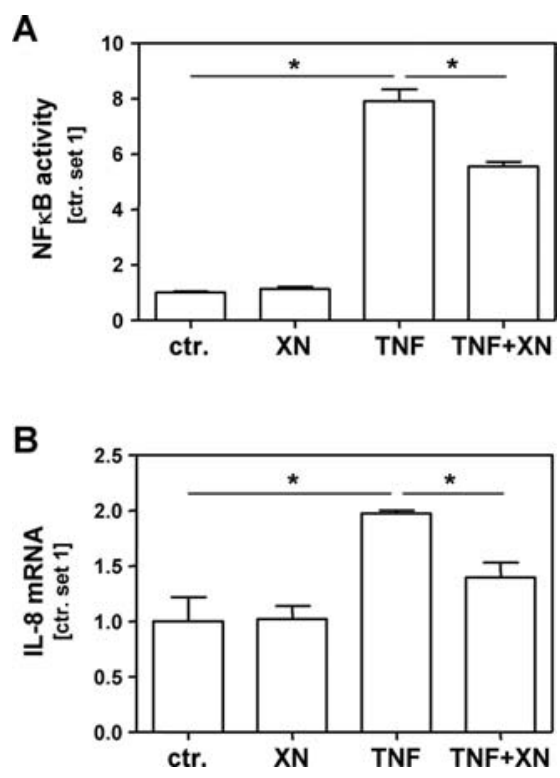

Figure 4. Effect of Xanthohumol on NF- $\mathrm{BB}$ activity and IL-8 mRNA expression in HCC cells. (A) Basal and TNF-induced (10 ng/ml, $15 \mathrm{~min}$ ) $\mathrm{NF}-\kappa \mathrm{B}$ activity in nuclear extracts of Huh7 cells, which were preincubated with xanthohumol (XN, $2.5 \mu \mathrm{M}, 3 \mathrm{~h})$, compared to control cells. (B) Analysis of basal and TNF (10 $\mathrm{ng} / \mathrm{ml}$ for $1 \mathrm{~h}$ ) induced IL- 8 mRNA expression by quantitative PCR. " $\mathrm{p}<0.05$, experiments were performed in triplicate and were repeated at least twice.

\section{Discussion}

In the present study we aimed to analyze the effects of xanthohumol on viability and tumorigenicity of HCC cells. 
We observed significant cell death in HCC cells upon stimulation with $\mathrm{XN}$ at a concentration of $25 \mu \mathrm{M}$, and analysis of the time course of caspase- 3 activation indicated that $\mathrm{XN}$ induced cell death is caused by apoptosis rather than other cytotoxic effects at this concentration, while XN concentration higher than $50 \mu \mathrm{M}$ led to a rapid and almost complete detachment of HCC cells in vitro. $\mathrm{XN}$ induced cell death has been described in cell lines derived from various cancers at similar concentrations as observed in the present study $(1,2,4,26-28)$. Thus, stimulation of prostate cancer cells with $20 \mu \mathrm{M} \mathrm{XN}$ resulted in an approximately halved viability (4), and XN concentration of $100 \mu \mathrm{M}$ induced $100 \%$ cell death in breast cancer cells (1). Recently, Ho et al reported that XN induced apoptosis in two HCC cell lines in vitro (29). However, in this study considerably higher XN concentrations (>200 $\mu \mathrm{M}$ ) were required to induce death of all HCC cells. One reason for this discrepancy might be the different HCC cell lines used (HA22T and Hep3B in the study of Ho et al, vs. HepG2 and Huh7 cells in our experiments). Furthermore, Ho et al used a hop extract containing $95.7 \%$ $\mathrm{XN}$ for their studies. Thus, confounding antagonizing effects of concomitant hop constituents can not be excluded.

In addition to viability, we analyzed functional effects of $\mathrm{XN}$ on HCC cells. Previous reports revealed an antiproliferative effect of $\mathrm{XN}$ on cancerous cells of different origin $(2,3,5,30)$. However, we are the first reporting a growth inhibitory effect of XN on HCC cells at concentrations as low as $15 \mu \mathrm{M}$. Most likely the analysis of anti-proliferative effects of $\mathrm{XN}$ is overlapped by its pro-apoptotic and cytotoxic effects. However, our dose-response studies clearly indicate that the significant anti-proliferative effect of XN observed already in the low concentration range can not be exclusively explained by these confounding mechanisms of XN action.

Of note, we further revealed that $\mathrm{XN}$ inhibits the migratory potential of HCC cells in vitro. Also with regard to migration, we chose conditions excluding that the observed effects of $\mathrm{XN}$ are only explained by confounding mechanisms on cell viability. To the best of our knowledge, an effect of XN on the migratory potential of cancerous cells has not been described in previous reports.

Furthermore, we demonstrated that $\mathrm{XN}$ inhibits TNF induced $\mathrm{NF}-\kappa \mathrm{B}$ activity in $\mathrm{HCC}$ cells in vitro, a situation that reflects the in vivo situation since $\mathrm{HCC}$ almost exclusively develops and progresses, respectively, on the basis of chronic liver inflammation (21). Furthermore, TNF and other members of the TNF superfamily are known to be capable of inducing cell death via death receptor mediated apoptosis pathways in tumor cells, and thus, appear attractive for cancer treatment (31). However, one of the major obstacles regarding their therapeutic application is the adaptive resistance due to activation of the $\mathrm{NF}-\kappa \mathrm{B}$ pathway $(32,33)$. Therefore, suppression of NF- $\mathrm{KB}$ appears as potential approach in overcoming the resistance to TNF induced apoptosis. Moreover, increased NF- $\mathrm{KB}$ activation is a common strategy of cancer cells to evade apoptosis, and further, has been shown to promote proliferation as well as migration of tumorous cells including $\mathrm{HCC}$ cells (17,34-37). In addition, NF-кB regulates the expression of the pro-inflammatory chemokine IL- 8 in HCC cells $(23,38)$, and previous studies have shown that IL-8 promotes the progression of HCC $(24,25)$.
Together, these data indicate the potential of $\mathrm{XN}$ as a therapeutic agent for HCC treatment. However, very few studies have addressed the important question whether $\mathrm{XN}$ exhibits (unwanted) effects on healthy tissue or non-tumorous cells, respectively. Yang et al described loss of viability in approximately $90 \%$ of 3T3-L1 cells, a murine adipocyte cell line, after $24 \mathrm{~h}$ treatment with $75 \mu \mathrm{M} \mathrm{XN}$ (39). In the (nonmalignant) murine hepatoma cell line AML12 the maximal applied concentration of $225 \mu \mathrm{M} \mathrm{XN}(24 \mathrm{~h})$ induced toxicity in approximately $50 \%$ of the cells as reported by Ho et al (29). However, to the best of our knowledge, no data have been reported concerning the effect of $\mathrm{XN}$ on primary human cells. In the present study we analyzed the effect of XN on the viability of primary human hepatocytes. Noteworthy, we found that viability of PHH was not affected after $24 \mathrm{~h}$ stimulation with a XN concentration as high as $100 \mu \mathrm{M}$. This is four-to ten-fold higher in comparison to the $\mathrm{XN}$ concentrations affecting viability and function of HCC cells under exactly the same experimental conditions.

These data further promote the use of $\mathrm{XN}$ as anti-cancer therapeutic, and first insight regarding bioavailability and metabolism of flavonoids and polyphenols suggest that particularly HCC appears as predestined cancer for oral XN treatment. Metabolism of flavonoids is rather complex and depends on the structure, the dose and the matrix, but there is evidence that several congeners reach (to a certain extend) the small intestine unchanged (40), where absorption into the mesenteric circulation takes place. Accordingly, it can be presumed that upon oral administration of XN hepatocytes as well as $\mathrm{HCC}$ cells are exposed to intact $\mathrm{XN}$ reaching the liver via portal circulation after absorption. In general, metabolism of most xenobiotics takes place in hepatocytes, and furthermore, it has been already shown that $\mathrm{XN}$ is effectively metabolized by rat and human liver microsomes in vitro (41-43). These studies suggest that $\mathrm{XN}$ is probably completely metabolized in the liver, and therefore, it may be predicted that circulating plasma concentrations will not reach potentially effective levels for most other cancers if $\mathrm{XN}$ is administered orally. This phenomenon is well-known for many other polyphenolic compounds (44).

In vivo studies in mice and rats $(45,46)$ as well as our in vitro experiments using human hepatocytes indicate a very good safety profile of XN. Still, further safety and efficacy studies are required to evaluate the suitability of $\mathrm{XN}$ as a therapeutic agent for HCC. However, the demonstrated pro-apoptotic, anti-proliferative, anti-migratory and anti-inflammatory effects of $\mathrm{XN}$ on HCC cells in vitro may act synergistically also in vivo, and herewith, $\mathrm{XN}$ appears as attractive and promising therapeutic agent for this highly aggressive tumor.

\section{Acknowledgements}

We would like to thank Birgitta Ott-Rötzer and Marina Fink for excellent technical assistance. This study was supported by grants from the German Research Association (He 2458/14-1 and Schn 620/3-1 to C.H.) and the Medical Faculty of the University of Regensburg (ReForM; to T.S.W. and C.H.). Further, this project was supported in part by an unrestricted research grant from the Joh. Barth \& Sohn $\mathrm{GmbH}$ (Nuremberg, Germany). Financial relationships of the 
authors with Joh. Barth \& Sohn GmbH are as follows: C.H. is a consultant, and C.D. is working in the laboratory of C.H.

\section{References}

1. Miranda CL, Stevens JF, Helmrich A, Henderson MC, Rodriguez RJ, Yang YH, Deinzer ML, Barnes DW and Buhler DR: Antiproliferative and cytotoxic effects of prenylated flavonoids from hops (Humulus lupulus) in human cancer cell lines. Food Chem Toxicol 37: 271-285, 1999.

2. Pan L, Becker $H$ and Gerhauser C: Xanthohumol induces apoptosis in cultured 40-16 human colon cancer cells by activation of the death receptor- and mitochondrial pathway. Mol Nutr Food Res 49: 837-843, 2005.

3. Vanhoecke B, Derycke L, Van MV, Depypere H, De KD and Bracke M: Antiinvasive effect of xanthohumol, a prenylated chalcone present in hops (Humulus lupulus L.) and beer. Int J Cancer 117: 889-895, 2005.

4. Colgate EC, Miranda CL, Stevens JF, Bray TM and Ho E: Xanthohumol, a prenylflavonoid derived from hops induces apoptosis and inhibits NF-kappaB activation in prostate epithelial cells. Cancer Lett 246: 201-209, 2007.

5. Delmulle L, Bellahcene A, Dhooge W, Comhaire F, Roelens F, Huvaere K, Heyerick A, Castronovo V and De KD: Antiproliferative properties of prenylated flavonoids from hops (Humulus lupulus L.) in human prostate cancer cell lines. Phytomedicine 13: 732-734, 2006.

6. Goto K, Asai T, Hara S, Namatame I, Tomoda H, Ikemoto M and Oku N: Enhanced antitumor activity of xanthohumol, a diacylglycerol acyltransferase inhibitor, under hypoxia. Cancer Lett 219: 215-222, 2005.

7. Hussain K and El-Serag HB: Epidemiology, screening, diagnosis and treatment of hepatocellular carcinoma: Minerva Gastroenterol Dietol 55: 123-138, 2009.

8. El-Serag HB and Mason AC: Rising incidence of hepatocellular carcinoma in the United States. N Engl J Med 340: 745-750, 1999.

9. El-Serag HB, Marrero JA, Rudolph L and Reddy KR: Diagnosis and treatment of hepatocellular carcinoma. Gastroenterology 134: 1752-1763, 2008.

10. Bruix J, Boix L, Sala M and Llovet JM: Focus on hepatocellular carcinoma. Cancer Cell 5: 215-219, 2004.

11. Farazi PA and DePinho RA: Hepatocellular carcinoma pathogenesis: from genes to environment. Nat Rev Cancer 6: 674-687, 2006.

12. Hellerbrand C, Bumes E, Bataille F, Dietmaier W, Massoumi R and Bosserhoff AK: Reduced expression of CYLD in human colon and hepatocellular carcinomas. Carcinogenesis 28: 21-27, 2007.

13. Hellerbrand C, Amann T, Schlegel J, Wild P, Bataille F, Spruss T, Hartmann A and Bosserhoff AK: The novel gene MIA2 acts as a tumour suppressor in hepatocellular carcinoma. Gut 57: 243-251, 2008.

14. Weiss TS, Jahn B, Cetto M, Jauch KW and Thasler WE: Collagen sandwich culture affects intracellular polyamine levels of human hepatocytes. Cell Prolif 35: 257-267, 2002.

15. Muhlbauer M, Fleck M, Schutz C, Weiss T, Froh M, Blank C, Scholmerich J and Hellerbrand C: PD-L1 is induced in hepatocytes by viral infection and by interferon-alpha and -gamma and mediates T cell apoptosis. J Hepatol 45: 520-528, 2006.

16. Hellerbrand C, Muhlbauer M, Wallner S, Schuierer M, Behrmann I, Bataille F, Weiss T, Scholmerich J and Bosserhoff AK: Promoter-hypermethylation is causing functional relevant downregulation of methylthioadenosine phosphorylase (MTAP) expression in hepatocellular carcinoma. Carcinogenesis 27: 64-72, 2006.

17. Amann T, Bataille F, Spruss T, Muhlbauer M, Gabele E, Scholmerich J, Kiefer P, Bosserhoff AK and Hellerbrand C: Activated hepatic stellate cells promote tumorigenicity of hepatocellular carcinoma. Cancer Sci 100: 646-653, 2009.

18. Muhlbauer M, Allard B, Bosserhoff AK, Kiessling S, Herfarth H, Rogler G, Scholmerich J, Jobin C and Hellerbrand C: Differential effects of deoxycholic acid and taurodeoxycholic acid on NFkappa B signal transduction and IL-8 gene expression in colonic epithelial cells. Am J Physiol Gastrointest Liver Physiol 286: G1000-G1008, 2004.

19. Muhlbauer M, Bosserhoff AK, Hartmann A, Thasler WE, Weiss TS, Herfarth H, Lock G, Scholmerich J and Hellerbrand C: A novel MCP-1 gene polymorphism is associated with hepatic MCP-1 expression and severity of HCV-related liver disease. Gastroenterology 125: 1085-1093, 2003.
20. Arsura M and Cavin LG: Nuclear factor-kappaB and liver carcinogenesis. Cancer Lett 229: 157-169, 2005.

21. Pikarsky E, Porat RM, Stein I, Abramovitch R, Amit S, Kasem S, Gutkovich-Pyest E, Urieli-Shoval S, Galun E and Ben-Neriah Y: NF-kappaB functions as a tumour promoter in inflammationassociated cancer. Nature 431: 461-466, 2004.

22. Iguchi A, Kitajima I, Yamakuchi M, Ueno S, Aikou T, Kubo T, Matsushima K, Mukaida N and Maruyama I: PEA3 and AP-1 are required for constitutive IL-8 gene expression in hepatoma cells. Biochem Biophys Res Commun 279: 166-171, 2000.

23. Joshi-Barve S, Barve SS, Amancherla K, Gobejishvili L, Hill D, Cave M, Hote $\mathrm{P}$ and McClain CJ: Palmitic acid induces production of proinflammatory cytokine interleukin- 8 from hepatocytes. Hepatology 46: 823-830, 2007.

24. Kubo F, Ueno S, Hiwatashi K, Sakoda M, Kawaida K, Nuruki K and Aikou T: Interleukin 8 in human hepatocellular carcinoma correlates with cancer cell invasion of vessels but not with tumor angiogenesis. Ann Surg Oncol 12: 800-807, 2005.

25. Ren Y, Poon RT, Tsui HT, Chen WH, Li Z, Lau C, Yu WC and Fan ST: Interleukin-8 serum levels in patients with hepatocellular carcinoma: correlations with clinicopathological features and prognosis. Clin Cancer Res 9: 5996-6001, 2003.

26. Lee SH, Kim HJ, Lee JS, Lee IS and Kang BY: Inhibition of topoisomerase I activity and efflux drug transporters' expression by xanthohumol from hops. Arch Pharm Res 30: 1435-1439, 2007.

27. Lust S, Vanhoecke B, Janssens A, Philippe J, Bracke M and Offner F: Xanthohumol kills B-chronic lymphocytic leukemia cells by an apoptotic mechanism. Mol Nutr Food Res 49: 844-850, 2005.

28. Monteiro R, Faria A, Azevedo I and Calhau C: Modulation of breast cancer cell survival by aromatase inhibiting hop (Humulus lupulus L.) flavonoids. J Steroid Biochem Mol Biol 105: 124-130, 2007.

29. Ho YC, Liu CH, Chen CN, Duan KJ and Lin MT: Inhibitory effects of xanthohumol from hops (Humulus lupulus L.) on human hepatocellular carcinoma cell lines. Phytother Res 22: 1465-1468, 2008.

30. Dell'Eva R, Ambrosini C, Vannini N, Piaggio G, Albini A and Ferrari N: AKT/NF-kappaB inhibitor xanthohumol targets cell growth and angiogenesis in hematologic malignancies. Cancer 110: 2007-2011, 2007.

31. Van HR, Ten Hagen TL and Eggermont AM: TNF-alpha in cancer treatment: molecular insights, antitumor effects, and clinical utility. Oncologist 11: 397-408, 2006.

32. Bertazza L and Mocellin S: Tumor necrosis factor (TNF) biology and cell death. Front Biosci 13: 2736-2743, 2008.

33. Falschlehner C, Emmerich CH, Gerlach B and Walczak H: TRAIL signalling: decisions between life and death. Int $J$ Biochem Cell Biol 39: 1462-1475, 2007.

34. Shen HM and Tergaonkar V: NFkappaB signaling in carcinogenesis and as a potential molecular target for cancer therapy. Apoptosis 14: 348-363, 2009.

35. Zhang S, Li J, Jiang Y, Xu Y and Qin C: Programmed cell death 4 (PDCD4) suppresses metastastic potential of human hepatocellular carcinoma cells. J Exp Clin Cancer Res 28: 71, 2009.

36. Salvi A, Sabelli C, Moncini S, Venturin M, Arici B, Riva P, Portolani N, Giulini SM, De PG and Barlati S: MicroRNA-23b mediates urokinase and c-met downmodulation and a decreased migration of human hepatocellular carcinoma cells. FEBS J 276: 2966-2982, 2009.

37. Shirouzu Y, Ryschich E, Salnikova O, Kerkadze V, Schmidt J and Engelmann G: Rapamycin inhibits proliferation and migration of hepatoma cells in vitro. J Surg Res (In press).

38. Dong G, Chen Z, Li ZY, Yeh NT, Bancroft CC and Van WC: Hepatocyte growth factor/scatter factor-induced activation of MEK and PI3K signal pathways contributes to expression of proangiogenic cytokines interleukin-8 and vascular endothelial growth factor in head and neck squamous cell carcinoma. Cancer Res 61: 5911-5918, 2001.

39. Yang JY, Della-Fera MA, Rayalam S and Baile CA: Effect of xanthohumol and isoxanthohumol on 3T3-L1 cell apoptosis and adipogenesis. Apoptosis 12: 1953-1963, 2007.

40. Spencer JP: Metabolism of tea flavonoids in the gastrointestinal tract. J Nutr 133: S3255-S3261, 2003.

41. Nikolic D, Li Y, Chadwick LR, Pauli GF and van Breemen RB: Metabolism of xanthohumol and isoxanthohumol, prenylated flavonoids from hops (Humulus lupulus L.), by human liver microsomes. J Mass Spectrom 40: 289-299, 2005. 
42. Yilmazer M, Stevens JF and Buhler DR: In vitro glucuronidation of xanthohumol, a flavonoid in hop and beer, by rat and human liver microsomes. FEBS Lett 491: 252-256, 2001.

43. Yilmazer M, Stevens JF, Deinzer ML and Buhler DR: In vitro biotransformation of xanthohumol, a flavonoid from hops (Humulus lupulus), by rat liver microsomes. Drug Metab Dispos 29: 223-231, 2001.

44. Scalbert A and Williamson G: Dietary intake and bioavailability of polyphenols. J Nutr 130: S2073-S2085, 2000.
45. Hussong R, Frank N, Knauft J, Ittrich C, Owen R, Becker H and Gerhauser C: A safety study of oral xanthohumol administration and its influence on fertility in Sprague Dawley rats. Mol Nutr Food Res 49: 861-867, 2005.

46. Vanhoecke BW, Delporte F, Van BE, Heyerick A, Depypere HT, Nuytinck M, De KD and Bracke ME: A safety study of oral tangeretin and xanthohumol administration to laboratory mice. In Vivo 19: 103-107, 2005. 